\title{
Construction of Higher Education Faculty Team Based on "Double 10-thousand Plan"
}

\author{
Jie Han \\ Academic Affairs Office \\ Northeastern University at Qinhuangdao \\ Qinhuangdao, China
}

\author{
Lianjie Ma * \\ Academic Affairs Office \\ Northeastern University at Qinhuangdao \\ Qinhuangdao, China
}

\author{
Leizhen Wang \\ Academic Affairs Office \\ Northeastern University at Qinhuangdao \\ Qinhuangdao, China
}

\begin{abstract}
The strategy of "double 10-thousand plan" has opened up a new era for the construction of China's higher education faculty team. In order to cultivate high-quality faculty team based on the "double 10-thousand plan", this work first expounded the problems existing in the construction of faculty team in China's universities. Then, by analyzing and comparing the experience for the construction of faculty team in world-famous universities, the measures to be taken in the construction of faculty team in China's universities were put forward combined with the actual situation. It includes strengthening top-level design, optimizing the structure of faculty team, combining scientific research with teaching, improving teaching evaluation system and teacher training system. The results offer some constructive suggestions and countermeasures for the construction in China's higher education faculty team.
\end{abstract}

Keywords-"Double 10-thousand plan"; Higher education; Faculty team construction; Talent training

\section{INTRODUCTION}

No matter how the times change, the position of faculty team construction in education is very important. Especially in today's society, the mission and responsibility of university teachers in education is particularly important. Especially on the premise that the state vigorously advocates the return to undergraduate education, the construction of higher education faculty team should formulate a new concept, and strive to build a new era of faculty team suited to the "double first-class" and "double 10-thousand plan". The construction goals of first-class universities and first-class majors can be truly realized. Therefore, the construction of faculty team should be a problem that higher education must face.

\section{ThE TIMES ORIENTATION IN THE CONSTRUCTION OF HigHER EDUCATION FACULTY TEAM BASED ON THE "DOUBLE 10-THOUSAND PLAN"}

In April 2019, the Ministry of Education announced the "Notice on the Implementation of the 'Double 10-thousand Plan' for the Construction in First-class Undergraduate Majors". This is an important measure following the announcement by the Ministry of Education in 2017 about "Notice on the
Announcement in the list of universities and construction disciplines for world-class universities and first-class disciplines". In 2018, at the national education congress, Chinese President Xi Jinping pointed out that: "Education is an important cornerstone of national rejuvenation and social progress, and is a moral and political project that is beneficial to the present and the future. It is of decisive significance for improving the comprehensive quality to the people, promoting the all-round development to the people, enhancing the creativity and creativity to the Chinese nation, and realizing the great rejuvenation to the Chinese nation. Education is the great plan of the country and the Party". In the new era, China's higher education is undergoing unprecedented changes.

Faculty team construction has always been an important focus in the development of higher education. The success or failure of a first-class university depends on the construction of first-class undergraduate major, and the construction of first-class undergraduate major is inseparable from the first-class faculty team. Therefore, the key factor in the construction of the "double 10-thousand plan" is to build a world-class faculty team. At present, faculty team construction has been regarded as a particularly important factor in the construction of the "double 10-thousand plan" in various universities.

\section{The Present Situation of FACUlty TEAM CONSTRUCTION IN CHINA'S UNIVERSITIES}

Since the founding of new China, the popularization rate and coverage of higher education in China have undergone tremendous changes. According to the data released by the Ministry of Education in 2019, the total scale of higher education in 2018 is 38.33 million. Compared with previous years, the scale of higher education in China continues to show a steady development trend, and the structure of higher education is further optimized. However, there are still obvious problems.

\section{A. The number of faculty team is insufficient}

In 2004, the Ministry of Education issued a circular on the "Indicators of Basic Conditions for Running Universities (For 
Trial Implementation)". It is clearly pointed out that the ratio of students to teachers in general undergraduate colleges should not exceed 18:1. Otherwise, the enrollment scale will be limited. In 2018, the ratio of students to teachers in general universities was $17.56: 1$. It is generally believed that the students to teachers ratio is the balance point of school running cost and quality. The lower the ratio of students to teachers indicates that teachers have more resources. Internationally, the ratio of students to teachers in higher education is usually 14:1. For example, the ratio of students to teachers at Harvard University and University of Cambridge is less than 10:1. However, the ratio of students to teachers in famous universities in China (e.g. Tsinghua University, Peking University) is higher than that in world-famous universities, and the national average students to teachers ratio is higher than the international standard. This result shows that there is a shortage of teachers in higher education in China. In order to cope with high-intensity teaching work, teachers in universities often reduce the time for personal quality improvement and academic research. So it can be seen that teachers' high-intensity teaching workload will inevitably affect the improvement of teaching quality and level.

\section{B. Lack of world-class and high-level faculty team}

The construction of "double 10-thousand plan" needs the world-class faculty team as the guarantee. Based on the number of alumni who won the Nobel Prize and the Fields Medal (referred to as "alumni award"), the number of teachers who won the Nobel Prize and the Fields Medal (referred to as "teacher award"), the number of scholars who were cited most frequently in various disciplines (referred to as "highly cited scholars"), the number of papers published in Nature and Science (referred to as "N\&S papers"), the number of papers collected by the Science Citation Index (SCIE) and the Social Science Citation Index (SSCI) (referred to as "International papers"), and the teacher average score of the above five indicators (referred to as "teachers' average performance"), etc., the Soft World University ranks the academic performance of world universities. The academic ranking data of Soft World Universities in 2019 (Table I) shows that there is still a big gap between the faculty of famous universities in China and world-famous universities. Therefore, China's universities need to continue to increase the import efforts, and strive to cultivate and build an influential team of scientists, subject leaders and teachers in the international academic frontier.

TABLE I. COMPARISON OF FACULTY BETWEEN TOP UNIVERSITIES IN CHINA AND TOP UNIVERSITIES IN THE WORLD

\begin{tabular}{|c|c|c|c|c|c|c|}
\hline School & $\begin{array}{c}\text { Harvard } \\
\text { University }\end{array}$ & $\begin{array}{l}\text { Stanford } \\
\text { University }\end{array}$ & $\begin{array}{l}\text { Cambridge } \\
\text { University }\end{array}$ & $\begin{array}{c}\text { Oxford } \\
\text { University }\end{array}$ & $\begin{array}{l}\text { Tsinghua } \\
\text { University }\end{array}$ & Peking University \\
\hline $\begin{array}{l}\text { Alumni awards } \\
\text { (Index score) }\end{array}$ & 100 & 45.2 & 80.7 & 48.9 & 9.7 & 11.2 \\
\hline $\begin{array}{l}\text { Teacher awards } \\
\text { (Index score) }\end{array}$ & 100 & 88.5 & 99.8 & 54.2 & 0 & 0 \\
\hline $\begin{array}{l}\text { Highly cited scholars } \\
\text { (Index score) }\end{array}$ & 100 & 73.3 & 53.9 & 56.3 & 37.4 & 32.8 \\
\hline $\begin{array}{c}\text { N\&S papers } \\
\text { (Index score) } \\
\end{array}$ & 100 & 79.2 & 58.1 & 55.1 & 39.2 & 31.5 \\
\hline $\begin{array}{c}\text { International papers } \\
\text { (Index score) }\end{array}$ & 100 & 76.6 & 71.9 & 78.8 & 79.5 & 76.0 \\
\hline $\begin{array}{c}\text { Teachers' average } \\
\text { performance(Index score) }\end{array}$ & 78.2 & 53.8 & 58.9 & 45.9 & 24.8 & 23.4 \\
\hline Academic total score & 100 & 75.1 & 72.3 & 59.7 & 35.4 & 32.2 \\
\hline
\end{tabular}

Data source: academic ranking of Soft World Universities in 2019

\section{The mechanism of talent introduction in universities is unreasonable}

Whether it is the first-class university construction or the current "double 10-thousand plan" construction, the introduction of high-level talents is an important task in the construction for the higher education faculty team. What is a high-level talent? Based on the recruitment announcements or talent introduction documents of major domestic universities, it is not difficult to find that the important indicators to talent introduction are often limited to the influencing factors of papers, the number of papers published, the number of citations and whether the administrative indicators of talent introduction can be completed quantitatively, etc. It neglects the role of introducing high-level talents in cultivating morality, cultivating students and promoting discipline construction. At the same time, in order to achieve the number of high-level talents, universities didn't mention the specific work plan and assessment requirements in the future when signing employment contracts with relevant experts, which brought hidden dangers for the ability to retain and use high-level talents well.

\section{The training mechanism of faculty team's structure is not perfect}

At present, the core work of faculty team construction is still the talent introduction. At the same time, there still exists the traditional concept on "emphasizing the use but neglecting the cultivation". Attention to the training of teachers and sustainable development is not enough, and a sound and complete training system of faculty team's structure in universities has not been formed. The published "double first-class" construction plan in universities shows that all universities lack the attention and policy guarantee to the whole group of teachers in the faculty team construction. It focuses on the training and development of "young and middle-aged backbone teachers". 


\section{SugGeStions ON THE CONSTRUCTION OF High-LEVEL FACULTY TEAM}

\section{A. Strengthening the top level design and optimizing the} faculty team's structure

Many China's universities have problems such as unreasonable proportion structure of teachers and lack of teaching echelon [1]. The leaders in universities should have the "wisdom eye" of conscious talents and the "selfless, enthusiasm and selfishness" of loving talents, establish the core idea of talent introduction, and consider all aspects of talent introduction thoroughly. They should unswervingly take the road of connotation-based faculty team to enhance the competitiveness in higher education in essence. Firstly, talent training and talent mining are carried out simultaneously. Secondly, the internal relationship between the stability and mobility of teachers should be dealt with reasonably and scientifically. Thirdly, faculty team should broaden the structure of academic margin, recruit well-known professors and excellent scholars through various channels, and enhance the attractiveness of high-end academic margin. Taking the construction of the "pyramid type" faculty team as the highest purpose, it is necessary to introduce and cultivate leading talents of the "spire" type, vigorously develop the "central part of the tower" type backbone teachers, and tap and cultivate the new force of "tower footing", so as to create a high level faculty team with reasonable structure and long-term development.

\section{B. Combination of scientific research and teaching}

At present, the understanding that "undergraduate is the foundation of university" is the same in the international higher education circles [2-3]. Many world-famous universities regard undergraduate education as the most important connotation of building first-class universities. The first-class teachers are the fundamental guarantee to promote the construction of the "double 10-thousand plan". How to establish a high-quality faculty team? First, it should increase the investment in teaching funds. Take this as the foundation; the investment in financial funds in teaching should be given priority. At the same time, schools should formulate relevant policies to focus on teacher performance, including job title assessment, teaching performance, etc., so as to encourage teachers to carry out teaching research and improve the overall teaching level. Second, it should guide teachers to invest more energy in teaching. The more time and energy teachers spend on teaching, the more innovative the teaching methods they adopt, and the quality of teaching will be improved. To achieve this goal, it is necessary to ensure that teachers can get a matching return after spending a lot of time and energy. Third, it should promote the teaching mode in combining teaching with scientific research. According to the actual situation, teachers will bring more scientific research results into the classroom, realize the integrated system of teaching with scientific research, coordinate production and teaching, and integrate theory with practice. They will constantly improve and enrich classroom teaching content, realize the combination of real teaching and scientific research, and promote and conspire with each other.

\section{Perfecting the teaching evaluation system}

Taking teaching quality as the core, the purpose of establishing an evaluation mechanism is to better face the problems in teaching, improve the teaching quality and teaching level [3-4]. First, it should cultivate a good teaching evaluation culture. Whether it is leadership evaluation, peer evaluation or student evaluation, the purpose is to improve the quality of teaching and improve the level of teaching. In this process, students are undoubtedly the biggest beneficiaries, and teachers can constantly improve teaching methods and change teaching content through feedback from leaders, peers and students. Second, it should construct diversified teaching evaluation indicators. Teaching and scientific research are important criteria for teachers' academic level, and they can't be measured by the same ruler. They should be evaluated differently. In view of the complexity in teaching process, the principles of teaching evaluation should follow large dimensions, many subjects and various forms. The evaluation indicators should cover all aspects in teaching process, so as to promote students' interest in learning and improve the quality of classroom teaching. Third, it should pay attention to the role of students' teaching evaluation results in teaching evaluation. Students are the direct experiences in teaching links and the core force in the whole teaching quality supervision system. Therefore, student evaluation of teaching is an important part for teaching quality control in universities. Universities should strive to change students' inherent thinking of teaching evaluation, fully listen to the voices of students, and guide students to participate actively in teaching evaluation. Students feel the important role of evaluation in a sincere manner, so as to reach the goal for attracting students to participate more actively in all aspects of classroom learning.

\section{Perfecting the teacher training system}

The faculty team construction in universities should not only rely on the introduction and evaluation of high-level teachers, but also pay attention to the development and cultivation of the existing faculty team [5-6]. Schools should establish corresponding incentive systems, relevant training and development mechanisms, so as to offer a good working environment for the improvement of existing teachers' abilities and healthy development. The overall level of faculty team has been improved. First, in order to promote teachers to continuously improve their abilities and levels, it should formulate a scientific and reasonable teacher reward and promotion mechanism. Second, it should establish a regular and long-term mechanism for teachers to visit schools abroad and let more teachers "go out" through various ways. Teachers should be trained in an international perspective, so that they can understand the talent training model in world-famous universities and the latest international academic trends and research results. Only in this way can we cultivate and build a first-class faculty team that matches famous international universities. Third, it should pay attention to the key role of school teacher development center platform in the construction for high-level teachers. Teacher development center serves to improve the quality of teaching and is an institution to promote the development of university teachers. Universities should fully rely on this platform to build a training model for teachers suitable for the sustainable development of the school. It 
provides a working environment for teachers to improve their teaching level and quality, and better contribute to the construction of the "double 10-thousand plan".

\section{CONCLUSION}

Based on the "double 10-thousand plan", the construction in higher education faculty team is an important link in personnel training. Therefore, the concept and training mode of talent introduction in universities should keep pace with the times and forge ahead. It should take the national policy as the guidance and discipline development as the direction, select and make good use of talents, and build a world-class faculty team for the construction of first-class universities and "double 10-thousand plan".

\section{REFERENCES}

[1] Shi Wenbin. Research on the Construction of the "Double First-class" Faculty Team in Universities in the New Era [J]. Talent Resources Development, 2019, 29-30.

[2] Zhang Yanli. Construction of First-class Faculty Team Based on the "Double First-class": Progress, Dilemma and Breakthrough-Taking Guangdong Vocational College of Post and Telecom as an Example[J]. University (Research Edition), 2017(6): 68-72.

[3] Luo Zhuhua, Liu Zehua, Wang Lifen. Development Strategy of Faculty Team Construction in Universities Focusing on First-class Undergraduate Education [J]. Higher Education Forum, 2019 (4): 31-34.

[4] Yao Yixia, Zhang Wenshun, He Jiudian. Problems and Thoughts on the Construction in First-class Undergraduate Faculty Team Based on the "Double First-class" Strategy [J]. Journal of Jiangxi Normal University (Philosophy and Social Sciences), 2018(2): 127-133.

[5] Duan Xu, Zhao Yangyi. On the Importance of Teacher Construction for College Teaching and Talent Cultivation-Taking Southwest Forestry University as an Example [J]. Curriculum Education Research, 2019(12): 6.

[6] Dang Yanhong. The Current Situation, Problems and Countermeasures of Teacher Mobility Based on "Double First-class" Construction [J]. Higher Education Research of Heilongjiang, 2018(9): 1-4. 